\title{
Extra-Adrenal Paraganglioma
}

National Cancer Institute

\section{Source}

National Cancer Institute. Extra-Adrenal Paraganglioma. NCI Thesaurus. Code C3309.

A benign or malignant parag ang lioma arising from sympathetic or parasympathetic parag ang lia outside the adrenal gland. 